\title{
The effect of a 5-week group-based exercise program on strength, balance, mobility, and gait in the older adult population: A pilot study
}

Shreena Chopra², Christine Dougherty², Mallory Johnston², Gina Curran² and Carol A. Maritz ${ }^{\text {* }}$

*Correspondence: c.maritz@usciences.edu

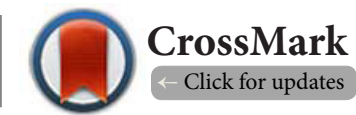

${ }^{1}$ Associate Dean and Professor of Physical Therapy, Samson College of Health Sciences, University of the Sciences, Philadelphia, PA 19104, USA.

${ }^{2}$ DPT student, University of the Sciences, Philadelphia, PA 19104, USA.

\begin{abstract}
Background: Falls are the fifth leading cause of death among adults aged 65 years and older. Lower extremity weakness and decreased balance are two important risk factors associated with falls in the older population. Current research suggests that in order to produce effective outcomes, an exercise program for older adults needs to be at least 10 weeks in length.

Methods: 18 of 23 participants over the age of 60 years (17 female, 1 male; mean age 74 years) completed this pre-test-post-test design. The participants tested on the following outcome measures: 30-second Chair Stand test for lower extremity strength, Four Square Step test (FSST) for dynamic balance, Timed Up and Go (TUG) test for mobility, Activity-Specific Balance Confidence scale (ABC) for balance confidence and GAITRite ${ }^{\circledR}$ for forward and backward walking velocity. Participants attended a 45-minute group-based exercise program twice a week for 5 weeks at a local church. The program included a 5 minute warm up, 10 minutes of stretching, 20 minutes of strengthening for both upper and lower extremities with resistance as well as core work, 5 minutes of balance training and 5 minutes of cool down exercises.

Results: A significant difference was found in the pre- and post-test measures of backward gait velocity $(\mathrm{p}=0.034)$, forward gait velocity $(\mathrm{p}=0.016), 30-\mathrm{SCST}(\mathrm{p}=0.001), \mathrm{TUG}(\mathrm{p}=0.022)$, and the FSST $(\mathrm{p}=0.001)$. Although there was no statistically significant differences found in the ABC scale, the overall scores increased.

Conclusion: This 5-week group-based exercise program was effective at improving forward and backward gait velocity as well as decreasing the clinical risk for falls in older adults. It is recommended that elements of this program be incorporated into physical therapy practice. Additionally, upon conclusion of physical therapy treatment, older adults should be encouraged to participate in community-based group exercise programs to maintain overall health and wellness and prevent future falls.
\end{abstract}

Keywords: Falls, gait, older adults, exercise

\section{Introduction}

Falls are the fifth leading cause of death among adults aged 65 years and older [1]. Each year, about one out of every three older adults falls, and one out of every five of these falls causes serious injuries, including broken bones or traumatic brain injury [2]. Life expectancy continues to increase in the United States with the elderly constituting a higher percentage of the population than ever before. This makes it critical that com- munities and healthcare professionals ensure the health and well-being of this population [3].

Lower extremity weakness and decreased balance are two important risk factors associated with falls in the older population [4-6]. When older adults fall, it is often in the backward direction, due in part to difficulty with backward stepping and mobility [7]. While forward walking speed has been used for years to identify those older adults at risk for falls, backward walking

(c) 2017 Maritz et al; licensee Herbert Publications Ltd. This is an Open Access article distributed under the terms of Creative Commons Attribution License (http://creativecommons.org/licenses/by/3.0). This permits unrestricted use, distribution, and reproduction in any medium, provided the original work is properly cited. 
velocity has been shown to be a more sensitive measure [8].

Current research suggests that in order to produce effective outcomes, an exercise program for older adults needs to be at least 10 weeks in length [9]. A program consisting of balance training, strengthening exercises, coordination activities, and a home exercise program have proven to be most beneficial in reducing falls risk in older adults [9-11].

To our knowledge, there are no studies that have examined the effectiveness of a 5 -week group-based exercise program at reducing falls risk in the older population. Therefore, the aims of this study were 1) to evaluate the impact of a group-based exercise program on clinical falls risk outcome measures, and 2) to determine the impact of a group-based exercise program on both forward and backward walking velocity and falls risk.

\section{Methods}

This quasi-experimental study included a sample of convenience of older adults recruited from a local church. All were community dwelling older adults over the age of 60 years, who were able to ambulate with or without an assistive device and demonstrated an ability to follow multi-step directions. Additionally, participants were excluded if they were disruptive to the group. The Institutional Review Board of University of the Sciences approved this study. All participants consented prior to participation.

As researchers, we were interested in evaluating the effectiveness of a 5-week group-based exercise program on falls risk. In the literature, falls risk is described as being related to lower extremity strength, balance, mobility, balance confidence and gait $[1,12,13]$. The participants were therefore tested on the following outcome measures: 30 -second Chair Stand test (30-sCST) for lower extremity strength, Four Square Step test (FSST) for dynamic balance, Timed Up and Go (TUG) test for mobility, Activity-Specific Balance Confidence scale (ABC) for balance confidence, and GAITRite ${ }^{\circledast}$ for forward and backward walking velocity (Table 1 ).

All subjects underwent pre- and post-testing in order to monitor their progress throughout the exercise program. The pre-test occurred one week prior to initiation of the program and the post-test occurred one week after the final session.

\section{Outcome Measures}

\section{The 30-Second Chair Stand Test (30-sCST)}

To perform this test, subjects were seated in a chair without arm rests. The height of the seat was 17 inches from the floor. They were asked to stand up and sit down as many times as they could in 30 seconds. The number of times that they could stand up was then recorded. This test provides insight into a person's lower body strength and endurance [14]. It links strength findings to the ability to perform everyday tasks such as climbing stairs, getting in and out of a vehicle or a bathtub [15]. This test has been shown to have excellent reliability with an ICC of 0.84 for males and 0.92 for females [14].

\section{The Four Square Step Test (FSST)}

The patient steps over four one inch pieces of PVC pipe setup similar to a cross on the floor [16]. Four Square Step test is a measure of dynamic balance that assesses the person's ability to step over objects forward, sideways, and backwards.

Community-dwelling older adults should be able to perform the FSST in less than 18 seconds [17]. This test has shown to have excellent inter-rater and test-retest reliability. The intra-class correlation coefficient (ICC) has been reported to be 0.99 and 0.98 respectively [16].

\section{Timed Up and Go Test (TUG)}

This test involves timing participants while they stand from being seated in a chair, walk 3 meters, turn around, walk back 3 meters and sit down. This test was performed 3 times, after which the average of the three trials (in seconds) was calculated and used for analysis. The Timed Up and Go test (TUG) is a standardized outcome measure used to assess mobility in older adults [18]. Community-dwelling older adults should be able to perform the TUG in less than 12 seconds [17]. The TUG was originally developed as a clinical measure to assess balance in the elderly, and it has shown to have excellent inter and intra-rater reliability.The intra-class correlation coefficient (ICC) has been reported to be $>0.95$ [19].

\section{The Activity Balance Confidence Scale (ABC)}

The Activities-Specific Balance Confidence scale (ABC Scale) is a 16-item self-report survey assessing the confidence someone has in their balance during certain activities [20]. The person rates their confidence on a scale of $0 \%$ (no confidence) to $100 \%$ (complete confidence) for each item. Age, as well as education level is factored into evaluating the data from the survey. The less confidence an individual has, the lower their scores will be on the survey, and they will have a higher risk for falls. The results also show that a higher percentage is correlated to being a more mobile, active, and functional person. This tool has excellent internal consistency with a Cronbach's alpha of 0.95 [21].

\section{Forward and Backward Walking}

ProtoKinetics Movement Analysis Software, PKMAS, (ProtoKinetics, LLC, Havertown, PA) was used to collect footfall data and compute spatiotemporal gait measures using an instrumented walkway, GAITRite ${ }^{\circledR}$ Mat(CIR Systems, Franklin, $\mathrm{NJ}$ ). The walkway consists of a $61 \times 366 \mathrm{~cm}$ carpet embedded with pressure sensors. Spatiotemporal gait measures collected on GAITRite ${ }^{\oplus}$ walkways have been found to be valid and reliable in the elderly [22-24].

Participants walked forward at a comfortable pace for 2 trials (down and back) on the 12-foot computerized walkway in order to familiarize themselves with the carpet. They then walked forward at a fast pace for 2 trials followed by 2 trials backwards. All trials included no fewer than 10 strides. Hollman et al found that data collected from 10-20 strides on the 
Chopra et al. Physical Therapy and Rehabilitation 2017,

http://www.hoajonline.com/journals/pdf/2055-2386-4-16.pdf

Table 1. Outcome measures utilized during 5-week training program.

\begin{tabular}{|c|c|c|c|}
\hline Outcome Measure & Purpose & Reliability & Validity \\
\hline $\begin{array}{l}\text { Timed Up and Go test } \\
\text { (TUG) }\end{array}$ & $\begin{array}{l}\text { Assesses mobility while test- } \\
\text { ing both static and dynamic } \\
\text { balance. In this test, an } \\
\text { individual will be required } \\
\text { to stand up from a seated } \\
\text { position, walk } 10 \text { feet, walk } \\
\text { around a cone, and then re- } \\
\text { turn to the chair and a seated } \\
\text { position. The individual is } \\
\text { timed. }{ }^{14}\end{array}$ & $\begin{array}{l}\text {-Test-retest (in elderly adults): } \\
\text { adequate ( } 0.56 \text { ICC) } \\
\text {-Inter-rater (in elderly adults): } \\
\text { excellent ( } 0.04 \text { seconds between } \\
\text { testers) }^{14}\end{array}$ & $\begin{array}{l}\text { - Concurrent (in elderly adults): } \\
\text { ability to predict fall risk showed } \\
\text { specificity of } 60 \% \text { and sensitivity } \\
\text { of } 56 \%{ }^{14} \\
\text { - Convergent (in community- } \\
\text { dwelling older adults): adequate } \\
\text { rating between other outcome } \\
\text { measures }(\mathrm{r}=-0.55-0.66)^{14}\end{array}$ \\
\hline Four Square Step test (FSST) & $\begin{array}{l}\text { Measures dynamic balance } \\
\text { and coordination through } \\
\text { stepping in four directions. } \\
\text { The individual is timed. } .^{15}\end{array}$ & $\begin{array}{l}\text {-Test-retest (in geriatrics): excel- } \\
\text { lent ( } 0.98 \text { ICC })^{15} \\
\text {-Inter-rater (in geriatrics): } \\
\text { excellent }(0.99 \text { ICC })^{15}\end{array}$ & $\begin{array}{l}\text {-Concurrent (geriatrics): excellent } \\
\text { with Step Test }(\mathrm{r}=-0.83) \text { and TUG } \\
(\mathrm{r}=0.88) \text { but fair with Functional } \\
\text { Reach }(\mathrm{r}=-0.47)^{15}\end{array}$ \\
\hline 30-second Chair Stand test & $\begin{array}{l}\text { Assesses lower extremity } \\
\text { strength and overall endur- } \\
\text { ance. An individual will rise } \\
\text { to a full standing position } \\
\text { and then descend to sitting } \\
\text { as many times as possible in } \\
30 \text { seconds. }{ }^{16}\end{array}$ & $\begin{array}{l}\text {-Test-retest (in community- } \\
\text { dwelling elderly): excellent } \\
\text { between total number of } \\
\text { participants }(\mathrm{r}=0.89) \text {, males } \\
(\mathrm{r}=0.84) \text {, and females }(\mathrm{r}=0.92)^{16} \\
\text {-Inter-rater (in community- } \\
\text { dwelling elderly): excellent } \\
(\mathrm{r}=0.95)^{16}\end{array}$ & $\begin{array}{l}\text {-Concurrent (in commu- } \\
\text { nity- dwelling elderly): excellent } \\
\text { compared with several other tests } \\
(\mathrm{r}=0.71-0.78)^{16}\end{array}$ \\
\hline $\begin{array}{l}\text { Activities-Specific Balance } \\
\text { Confidence (ABC) scale }\end{array}$ & $\begin{array}{l}\text { Self assesses an individual's } \\
\text { confidence while perform- } \\
\text { ing different, everyday tasks. } \\
\text { The individual is asked to } \\
\text { rate how confident they are } \\
\text { while performing a variety } \\
\text { of tasks on a percentage scale } \\
\text { of } 0-100 \% \text {. This measure is } \\
\text { subjective and helps quantify } \\
\text { confidence in the commu- } \\
\text { nity in relation to falls. }{ }^{17}\end{array}$ & $\begin{array}{l}\text {-Test-retest (in elderly): } \\
\text { excellent }(r=0.92)^{17}\end{array}$ & $\begin{array}{l}\text {-Concurrent (in geriatric } \\
\text { females): varies with correlation } \\
\text { of other tests }(-0.65-0.57)^{17}\end{array}$ \\
\hline $\begin{array}{l}\text { GAITRite }{ }^{\infty} \text { Computerized } \\
\text { Walkway System and } \\
\text { Protokinetics Movement } \\
\text { Analysis Software PKMAS } \\
\text { software system }\end{array}$ & $\begin{array}{l}\text { Evaluates gait during back- } \\
\text { ward and forward walking. } \\
\text { Analysis includes velocity, } \\
\text { step length, cadence, stride } \\
\text { length, etc. }{ }^{18}\end{array}$ & $\begin{array}{l}\text {-Excellent correlation in one } \\
\text { healthy woman }(\text { ICC }>95) \text { for } \\
\text { spatial measures } \\
\text {-Excellent correlation in one } \\
\text { healthy woman (ICC >93) for } \\
\text { video-based temporal mea- }_{\text {sures }^{18}}\end{array}$ & $\begin{array}{l}\text {-“Measures of step lengths and } \\
\text { times were reliable in both } \\
\text { walkway center and left-of center } \\
\text { measurements" in one healthy } \\
\text { woman }{ }^{18}\end{array}$ \\
\hline
\end{tabular}

GAITRite $^{\circledast}$ Mat(CIR Systems, Franklin, NJ)

ProtokineticsMovement Analysis Software, PKMAS, (ProtoKinetics, LLC, Havertown, PA)

GAITRite ${ }^{\circledR}$ were found to be a reliable method for measuring velocity and cadence [25]. All participants were instructed to walk 2 meters before and after the walkway to allow for acceleration and deceleration. All trials were completed without an assistive device while wearing a gait belt and guarded by one member of the research team. Forward and backward walking velocity $(\mathrm{cm} / \mathrm{sec})$ were analyzed.

\section{Intervention}

This study's principal investigator and physical therapist designed the exercise program using current evidence-based programs as a guide to specifically address falls risk factors. The classes were conducted twice weekly for 5 weeks in the base- ment of a local church. The program began with a 10-minute warm up that included standing exercises for major muscle groups and general flexibility exercises. Lower extremity strengthening exercises using weights and resistance bands were performed both in the seated position and standing. Upper extremity resisted exercises also used a combination of weights and bands, and were performed seated to ensure proper performance. Functional exercises such as repeated sit to stand, squats, and lunges were part of the program. The sustained exercise during each class promoted cardiovascular conditioning. Static and dynamic balance activities included single leg stance and tandem stance, as well as repetitive stepping with increasing speed of performance. A cool-down 
Chopra et al. Physical Therapy and Rehabilitation 2017,

http://www.hoajonline.com/journals/pdf/2055-2386-4-16.pdf

doi: 10.7243/2055-2386-4-16

period consisted of gentle active exercises in sitting (Table 2).

All exercises were performed to music that was selected by the participants. The complexity and speed of exercise and the amount of resistance were all steadily increased over the course of the program. Each class lasted 45-50 minutes with

Table 2. Interventions implemented during every training session throughout the 5-week program.

\begin{tabular}{|c|c|}
\hline \\
\hline \multicolumn{2}{|l|}{ Warm up (standing) (5 minutes) } \\
\hline & Side Stepping \\
\hline & Leg Kicks \\
\hline & Knees to chest \\
\hline & Scapular retraction \\
\hline & Forward/Backward Stepping \\
\hline & Shoulder press \\
\hline \multirow{8}{*}{$\begin{array}{l}\text { Stretching (seated and standing) } \\
\text { (10 minutes) }\end{array}$} & Cervical Rotation \\
\hline & Cervical Lateral Flexion \\
\hline & Seated Trunk Rotation \\
\hline & Seated Hamstring/Calf \\
\hline & Shoulder Posterior Capsule \\
\hline & Standing Calf \\
\hline & Standing IT Band \\
\hline & Standing Lateral Trunk Flexion \\
\hline \multirow{10}{*}{$\begin{array}{l}\text { Lower Extremity Strengthening } \\
\text { (seated and standing) } \\
\text { (10 minutes) } \\
\text { Cuff weights }\end{array}$} & Seated Knee Extension \\
\hline & Seated Hip Flexion \\
\hline & Standing Knee Flexion \\
\hline & Standing Hip Abduction \\
\hline & Standing Hip Flexion \\
\hline & Standing Hip Extension \\
\hline & Unilateral Heel Raises \\
\hline & Sit to Stand \\
\hline & Sumo Squats \\
\hline & Chair Squats \\
\hline \multirow{2}{*}{$\begin{array}{l}\text { Core Strengthening } \\
\text { (seated and standing) } \\
\text { ( } 5 \text { minutes) }\end{array}$} & Chair Sit Ups \\
\hline & PNF Chops and Lifts \\
\hline \multirow{5}{*}{$\begin{array}{l}\text { Upper Extremity (seated) } \\
\text { Strengthening } \\
\text { ( } 5 \text { minutes) } \\
\text { Using dumbbell and exercise bands }\end{array}$} & Biceps Curls \\
\hline & Triceps Extension \\
\hline & Overhead Press \\
\hline & Internal/External Rotation \\
\hline & Upper Extremity PNF (D2) \\
\hline \multirow{4}{*}{$\begin{array}{l}\text { Balance (standing) } \\
\text { (5 minutes) }\end{array}$} & Single Leg Balance \\
\hline & Tandem Stance \\
\hline & Dynamic Single Leg Balance \\
\hline & Dynamic Stepping with Cues \\
\hline \multirow{3}{*}{$\begin{array}{l}\text { Cool Down (seated) } \\
\text { (5 minutes) }\end{array}$} & Seated Marches \\
\hline & Seated Knee Kicks \\
\hline & $\begin{array}{l}\text { Seated Hip Abduction/ } \\
\text { Adduction } \\
\text { Seated Ankle Pumps }\end{array}$ \\
\hline
\end{tabular}

rest breaks as needed. Attendance was taken each session. The majority of participants were members of the church and had pre-existing relationships with one another.

Statistical analysis was performed using IBM ${ }^{\circledast}$ SPSS statistics software package (24.0). Non-parametric analysis, specifically, the Wilcoxon Signed Rank test, was used to analyze change in duration and velocity from baseline measurements due to the fact that the data was not normally distributed. The level of significance was set at $\mathrm{P}<0.05$.

\section{Results}

18 participants of the initial 23 ( 17 female, 1 male; mean age 74 years) completed the study (Table 3 ). 3 subjects were lost to follow up and 1 subject did not complete all of the outcome measures due to issues relating to vertigo.

Table 3. Demographics of training program participants.

\begin{tabular}{ll}
\hline Variable & \\
\hline Mean Age (years) & 74 years \\
Sex (male/female) & 1 male/17 females \\
History of recent fall(s) & 1 participant/1 fall \\
Use of Assistive Device & 2 (cane) \\
\hline
\end{tabular}

A significant difference was found in the pre- and post-test measures of backward gait velocity $(p=0.034)$, forward gait velocity $(p=0.016), 30$-second Chair Stand test $(p=0.001)$, TUG $(p=0.022)$, and the FSST $(p=0.001)$. Although there was no statistically significant differences found in the $A B C$ scale $(p=0.528)$, the overall scores increased (Table 4).

\section{Discussion}

This study examined the effects of a moderate intensity 5 -week group-based exercise program on balance, lower extremity strength, and functional mobility in older adults 60 years of age and older. Although the duration of the program was significantly shorter than the 12 weeks that current evidence suggests in order for change to occur, the results of this study support the supposition that a moderate intensity exercise program of 5 weeks in duration can lead to measurable changes in lower extremity strength, balance and gait while also decreasing risk for falls.

Older adults who participated in a 5-week group-based exercise program demonstrated an increase in their gait velocity with both forward and backward walking. Along with improved gait velocity, there was also a general increase in balance confidence. Although not statistically significant, the increase in scores is clinically significant. Since the program focused on overall body strength, balance, and mobility to help the subjects improve their confidence and safety while ambulating within their community, it stands to reason that confidence would improve. With this improved confidence, individuals have an increased participation in community activities $[6,26,27]$. 
Chopra et al. Physical Therapy and Rehabilitation 2017,

http://www.hoajonline.com/journals/pdf/2055-2386-4-16.pdf

Table 4. Outcome measure results after pre- and post- testing.

\begin{tabular}{|c|c|c|c|c|c|}
\hline Tests/Measures & Pre-Testing Mean & $\begin{array}{l}\text { Pre-Testing Standard } \\
\text { Deviation }\end{array}$ & $\begin{array}{l}\text { Post-Testing } \\
\text { Mean }\end{array}$ & $\begin{array}{l}\text { Post-Testing Standard } \\
\text { Deviation }\end{array}$ & P-Value \\
\hline $\begin{array}{l}\text { Forward Walking Velocity } \\
(\mathrm{cm} / \mathrm{sec})\end{array}$ & 109.9 & 12.0 & 118.3 & 16.5 & $.016^{\star}$ \\
\hline $\begin{array}{l}\text { Backward Walking Velocity } \\
(\mathrm{cm} / \mathrm{sec})\end{array}$ & 62.0 & 15.9 & 67.9 & 18.3 & $.034^{\star}$ \\
\hline $\begin{array}{l}\text { 30-Second Chair Stand Test } \\
\text { (repetitions) }\end{array}$ & 12.7 & 3.3 & 15.5 & 3.2 & $.001^{\star}$ \\
\hline Timed Up and Go Test (sec) & 9.8 & 1.9 & 9.1 & 1.9 & $.022^{\star}$ \\
\hline Four Square Step Test (sec) & 11.5 & 3.1 & 10.0 & 2.1 & $.001^{\star}$ \\
\hline $\begin{array}{l}\text { Activities-Specific Balance } \\
\text { Confidence (ABC) Scale }\end{array}$ & 85.6 & 8.9 & 86.5 & 12.6 & .528 \\
\hline
\end{tabular}

In this study, subjects' falls risk decreased as their forward gait velocity improved (Table 3). A study by Verghese et al [28] found that individuals over the age of 70 with a forward gait velocity of less than $100 \mathrm{~cm} / \mathrm{s}$ have an increased falls risk. Several participants in our study began with forward gait velocity below the threshold of $100 \mathrm{~cm} / \mathrm{s}$, but showed improvements throughout the program, resulting in a decrease in their falls risk. Overall, the forward gait velocity data points were found to be statistically significant when comparing pre- and post-testing (Table 5) [29].

Fritz et al [8] examined backward walking in individuals over the age of 65 to determine the effects of age on gait. Those who had a gait velocity of less than $60 \mathrm{~cm} / \mathrm{s}$ were found to have an increased falls risk [8]. Similarly, some subjects in our study were below this threshold at the start of the program but demonstrated increased backward gait velocity at the conclusion of the program, decreasing their falls risk (Table 6).

Our participants engaged in exercise activities with agerelated peers from the same church or living community. We infer that this closeness promoted a collegiality that fostered a motivating environment for those who needed external means of encouragement. This group support may be part of the explanation as to why there were significant improve-

Table 5. Forward mean gait velocity pre- and post- testing in comparison to a $100 \mathrm{~cm} / \mathrm{s}$ threshold.

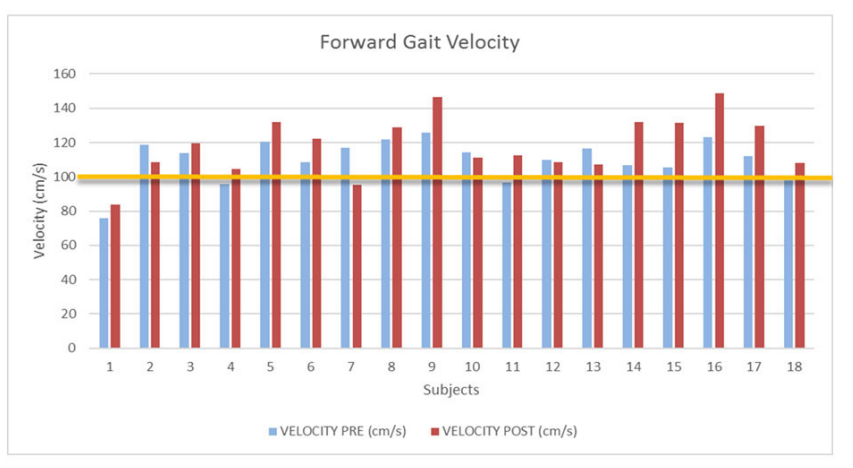

$100 \mathrm{~cm} / \mathrm{s}$ Threshold (Verghese et al) ments in just 5-weeks, despite previous studies finding a much longer duration to achieve change.

Table 6. Backward mean gait velocity pre- and post- testing in comparison to a $60 \mathrm{~cm} / \mathrm{s}$ threshold.

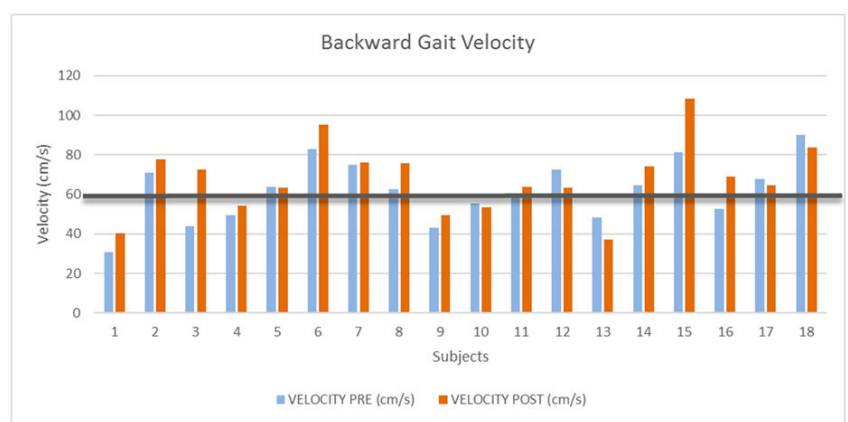

$60 \mathrm{~cm} / \mathrm{s}$ Threshold (Fritz et al)

This study had a number of limitations including the use of a sample of convenience instead of having a control group. The absence of a control group makes it difficult to identify what part of the program had the greatest effect, the exercise program or the social interaction between group members. However, since there was significance in several variables, one can assume that the main effect was due to the exercises. Further randomized controlled trials are needed. Although the sample size was small, it did not seem to impact the ability to see a difference in function with treatment. Despite these limitations, significant improvements were detected over time, which indicates that this type of exercise program might be of great benefit to the older population. There were also some technological errors with the GAITRite ${ }^{\circledast}$ system which led to a few subjects being disqualified from the results because of improper registration of their footfalls.

\section{Conclusion}

Based on the data that has been collected through this study, it can be inferred that this 5-week group-based exercise program has shown to be effective in improving forward 
and backward gait velocity, and decreasing the clinical risk for falls in older adults. Based upon the results obtained, elements of this exercise program should be incorporated into physical therapy practice, with sessions that are focused on achieving improved gait velocity and decreased falls risk in older adults. Additionally, upon conclusion of physical therapy treatment, older adults should continue to participate in a community-based group exercise program in order to improve strength, balance, and mobility to enhance overall health and wellness and prevent future falls.

\section{List of abbreviations}

30-sCST: 30-second Chair Stand test

FSST: Four Square Step test

TUG: Timed Up and Go test

ABC: Activity-Specific Balance Confidence scale

\section{Competing interests}

The authors declare that they have no competing interests.

Authors' contributions

\begin{tabular}{|l|c|c|c|c|c|}
\hline Authors' contributions & SC & CD & MJ & GS & CAM \\
\hline Research concept and design & -- & -- & -- & -- & $\checkmark$ \\
\hline Collection and/or assembly of data & $\checkmark$ & $\checkmark$ & $\checkmark$ & $\checkmark$ & $\checkmark$ \\
\hline Data analysis and interpretation & $\checkmark$ & $\checkmark$ & $\checkmark$ & $\checkmark$ & $\checkmark$ \\
\hline Writing the article & $\checkmark$ & $\checkmark$ & $\checkmark$ & $\checkmark$ & $\checkmark$ \\
\hline Critical revision of the article & -- & -- & -- & -- & $\checkmark$ \\
\hline Final approval of article & $\checkmark$ & $\checkmark$ & $\checkmark$ & $\checkmark$ & $\checkmark$ \\
\hline Statistical analysis & -- & -- & $\checkmark$ & -- & -- \\
\hline
\end{tabular}

\section{Acknowledgement}

A special thank you to the participants of Mount

Zion SWEET program for their unwavering

commitment to their health and well-being.

Publication history

Editor: Mohammad H. Hadadzadeh, Wheeling Jesuit University, USA. Received: 02-Aug-2017 Final Revised: 09-Oct-2017

Accepted: 16-Nov-2017 Published: 26-Nov-2017

\section{References}

1. Rubenstein LZ. Falls in older people: epidemiology, risk factors and strategies for prevention. Age Ageing. 2006; 35 Suppl 2:ii37-ii41. | Article | PubMed

2. Important Facts about Falls. Home and Recreational Safety. CDC Injury Center, (n.d.). 2016. I Website

3. C. Todd and D. Skelton, What are the main risk factors for falls amongst older people and what are the most effective interventions to prevent these falls? World Health. 2004. I Pdf

4. Cronin NJ, Barrett RS, Lichtwark G, Mills PM and Carty CP. Decreased lower limb muscle recruitment contributes to the inability of older adults to recover with a single step following a forward loss of balance. J Electromyogr Kinesiol. 2013; 23:1139-44. | Article | PubMed

5. Melzer I, Krasovsky T, Oddsson LI and Liebermann DG. Age-related differences in lower-limb force-time relation during the push-off in rapid voluntary stepping. Clin Biomech (Bristol, Avon). 2010; 25:989-94. | Article | PubMed

6. Murphy SL, Williams CS and Gill TM. Characteristics associated with fear of falling and activity restriction in community-living older persons. $J$
Am Geriatr Soc. 2002; 50:516-20. | Article | PubMed Abstract | PubMed FullText

7. Laufer Y. Effect of age on characteristics of forward and backward gait at preferred and accelerated walking speed. J Gerontol A Biol Sci Med Sci. 2005; 60:627-32. | Article | PubMed

8. Fritz NE, Worstell AM, Kloos AD, Siles AB, White SE and Kegelmeyer DA. Backward walking measures are sensitive to age-related changes in mobility and balance. Gait Posture. 2013; 37:593-7. | Article | PubMed

9. Sherrington C, Tiedemann A, Fairhall N, Close JC and Lord SR. Exercise to prevent falls in older adults: an updated meta-analysis and best practice recommendations. N S W Public Health Bull. 2011; 22:78-83. | Article I PubMed

10. Barnett A, Smith B, Lord SR, Williams M and Baumand A. Communitybased group exercise improves balance and reduces falls in at-risk older people: a randomised controlled trial. Age Ageing. 2003; 32:407-14. | Article I PubMed

11. Kim WJ, Chang M and An DH. Effects of a Community-based Fall Prevention Exercise Program on Activity Participation. J Phys Ther Sci. 2014; 26:651-3. | Article | PubMed Abstract | PubMed FullText

12. Ambrose $A F$, Paul $G$ and Hausdorff JM. Risk factors for falls among older adults: a review of the literature. Maturitas. 2013; 75:51-61. | Article | PubMed

13. Moreland JD, Richardson JA, Goldsmith CH and Clase CM. Muscle weakness and falls in older adults: a systematic review and metaanalysis. J Am Geriatr Soc. 2004; 52:1121-9. | Article | PubMed

14. Jones CJ, Rikli RE and Beam WC. A 30-s chair-stand test as a measure of lower body strength in community-residing older adults. Res $Q$ Exerc Sport. 1999; 70:113-9. | Article | PubMed

15. Chandler JM, Duncan PW, Kochersberger G and Studenski S. Is lower extremity strength gain associated with improvement in physical performance and disability in frail, community-dwelling elders? Arch Phys Med Rehabil. 1998; 79:24-30. | Pdf | PubMed

16. Dite $W$ and Temple VA. A clinical test of stepping and change of direction to identify multiple falling older adults. Arch Phys Med Rehabil. 2002; 83:1566-71. | Article | PubMed

17. Bischoff HA, Stahelin HB, Monsch AU, Iversen MD, Weyh A, von Dechend $\mathrm{M}$, Akos R, Conzelmann M, Dick W and Theiler R. Identifying a cut-off point for normal mobility: a comparison of the timed 'up and go' test in community-dwelling and institutionalised elderly women. Age Ageing. 2003; 32:315-20. | Article | PubMed

18. Podsiadlo D and Richardson S. The timed "Up \& Go": a test of basic functional mobility for frail elderly persons. J Am Geriatr Soc. 1991; 39:142-8. | Article | PubMed

19. Schoene D, Wu SM, Mikolaizak AS, Menant JC, Smith ST, Delbaere K and Lord SR. Discriminative ability and predictive validity of the timed up and go test in identifying older people who fall: systematic review and meta-analysis. J Am Geriatr Soc. 2013; 61:202-8. | Article | PubMed

20. Myers AM, Fletcher PC, Myers AH and Sherk W. Discriminative and evaluative properties of the activities-specific balance confidence (ABC) scale. J Gerontol A Biol Sci Med Sci. 1998; 53:M287-94. | Article | PubMed

21. Talley KM, Wyman JF and Gross CR. Psychometric properties of the activities-specific balance confidence scale and the survey of activities and fear of falling in older women. J Am Geriatr Soc. 2008; 56:328-33. | Article I PubMed

22. Bilney B, Morris M and Webster K. Concurrent related validity of the GAITRite walkway system for quantification of the spatial and temporal parameters of gait. Gait Posture. 2003; 17:68-74. | Article | PubMed

23. Menz HB, Latt MD, Tiedemann A, Mun San Kwan M and Lord SR. Reliability of the GAITRite walkway system for the quantification of temporo-spatial parameters of gait in young and older people. Gait Posture. 2004; 20:20-5. | Article | PubMed

24. Egerton T, Thingstad $P$ and Helbostad JL. Comparison of programs for determining temporal-spatial gait variables from instrumented walkway data: PKmas versus GAITRite. BMC Res Notes. 2014; 7:542. | Article | PubMed Abstract | PubMed FullText 
Chopra et al. Physical Therapy and Rehabilitation 2017,

http://www.hoajonline.com/journals/pdf/2055-2386-4-16.pdf

25. Hollman JH, Childs KB, McNeil ML, Mueller AC, Quilter CM and Youdas JW. Number of strides required for reliable measurements of pace, rhythm and variability parameters of gait during normal and dual task walking in older individuals. Gait Posture. 2010; 32:23-8. | Article | PubMed

26. Friedman SM, Munoz B, West SK, Rubin GS and Fried LP. Falls and fear of falling: which comes first? A longitudinal prediction model suggests strategies for primary and secondary prevention. J Am Geriatr Soc. 2002; 50:1329-35. | Article | PubMed

27. Wijlhuizen GJ, de Jong R and Hopman-Rock M. Older persons afraid of falling reduce physical activity to prevent outdoor falls. Prev Med. 2007; 44:260-4. | Article I PubMed

28. Verghese J, Wang C, Lipton RB, Holtzer R and Xue X. Quantitative gait dysfunction and risk of cognitive decline and dementia. J Neurol Neurosurg Psychiatry. 2007; 78:929-35. | Article | PubMed Abstract | PubMed FullText

29. Verghese J, Holtzer R, Lipton RB and Wang C. Quantitative gait markers and incident fall risk in older adults. J Gerontol A Biol Sci Med Sci. 2009; 64:896-901. | Article | PubMed Abstract | PubMed FullText

\section{Citation:}

Chopra S, Dougherty C, Johnston M, Curran G and Maritz CA. The effect of a 5-week group-based exercise program on strength, balance, mobility, and gait in the older adult population: A pilot study. Phys Ther Rehabil. 2017; 4:16.

http://dx.doi.org/10.7243/2055-2386-4-16 